\title{
Выращивание огурца в весенне-летней теплице с применением биопрепаратов
}

\section{Р.А. Арсланова, Л.П. Ионова, Ж.А. Вилкова, А.С. Бабакова, М.Ю. Анишко}

Представлены результаты исследований по изучению влияния биопрепаратов Биогумус, Гуми и Альбит на растения раннеспелых гибридов огурца в защищенном грунте. В ходе работы установлено, что своевременные подкормки биопрепаратами отзывчивых на их внесение гибридов, способствовали повышению ростовых процессов растений, от прорастания семян до конца плодоношения, увеличению урожайности и товарности плодов.

Ключевые слова: защищенный грунт, гибриды огурца, биопрепараты, продуктивность растений, товарная урожайность плодов.

$\mathrm{O}$ гурец - одна из наиболее широко распространенных и охотно потребляемых населением овощных культур. Выращивание огурцов в защищенном грунте позволяет использовать их свежими и ароматными круглогодично. Доказано, что микро-, мезои макроэлементы, а также регуляторы роста и биологически активные вещества (БАВ) играют важную роль в повышении урожайности [1].

Цель наших исследований: оценка действия БАВ на рост и развитие раннеспелых гибридов огурца в весенне-летней теплице и увеличение товарной урожайности плодов. Для опыта нами были выбраны биопрепараты Биогумус, Гуми и Альбит, а также раннеспелые гибриды огурца отечественной и голландской селекции (отечественные - $F_{1}$ Чистые пруды, $F_{1}$ Апрельский, $F_{1}$ Арина, $F_{1}$ Кураж и голландские $-F_{1}$ Маша, $F_{1}$ Герман). Научная новизна: впервые оценена эффективность данных биопрепаратов на раннеспелых гибридах огурца.

Опыт закладывали в 2017-2018 годах в пленочной теплице по методике Б.А. Доспехова [2]. Подкормки биопрепаратами проводили согласно схемы опыта (табл. ). Сборы огурцов по гибридам проводили регулярно через день в фазу массового плодоношения и через 2-3 дня в начале и в конце плодоношения.

Один из наиболее важных факторов роста и развития растений огурца - питание растений $[3,4,5$, 6]. Применение биопрепаратов стимулировало рост и развитие растений, а также способствовало сокращению количества дней при прохождении фаз развития, при обработке растений Биогумусом и Гуми на 5-8 дней, Альбитом на 3-4 дня, по сравнению с контрольными растениями. Наиболее раннее начало образования завязей зафиксировано в вариантах с Биогумусом на гибридах $F_{1}$ Кураж и Гуми на гибридах $F_{1}$ Чистые пруды и $\mathrm{F}_{1}$ Апрельский, в среднем на 4-7 дней по сравнению с контролем.

В фазу массового образования завязей была проведена обработка растений биопрепаратами методом опрыскивания, что сократило фазу образования завязей на 2-8 дней, по сравнению с контролем, по всем гибридам. В фазу плодоношения гибриды огур- ца вступали неодинаково, в зависимости от биологических особенностей каждого гибрида и вида биопрепарата. Самый ранний сбор первых плодов по сравнению с контролем раньше на 8-10 дней в варианте с Биогумусом, с Гуми на 4-8 дней, с Альбитом на 4-5 дней, соответственно. Второй сбор плодов в варианте с Биогумусом отмечен на 4-7 день, с Гумми на 5-6 день, с Альбитом на 4-7 день, в контроле на 10-12 день. В целом применение биопрепаратов способствовало сокращению вегетационного периода по всем гибридам. Наиболее отзывчивыми на биопрепараты оказались гибриды $F_{1}$ Кураж, $F_{1}$ Апрельский, $F_{1}$ Арина и $F_{1}$ Маша. У этих гибридов повышалось количество завязей и зеленцов по сравнению с контролем [3, 6].

В наших исследованиях мы также провели наблюдения за ростом листовой поверхности по фазам вегетации. По скорости нарастания площади листовой поверхности растения огурца можно разделить на две группы. В первой группе выделялись два гибрида ( $F_{1}$ Апрельский и $F_{1}$ Арина), которые имели наиболее мощные листовые поверхности, площадь каждой из них в фазу массового

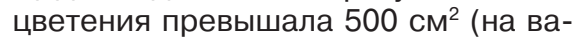
риантах с использованием биопрепаратов Гуми и Альбит) и в фазу массового плодоношения при обработке Альбитом достигала 580-590 см². Ко второй группе можно отнести следующие гибриды: $F_{1}$ Чистые пруды, $F_{1}$ Кураж, $F_{1}$ Маша и $F_{1}$ Герман. Если рассматривать в среднем динамику увеличения листовой поверхности по

\section{Схема опыта, 2017-2018 годы}

\begin{tabular}{|c|c|c|c|c|}
\hline \multirow{3}{*}{$\begin{array}{l}\text { Вариант } \\
\text { опыта }\end{array}$} & \multicolumn{4}{|c|}{ Вид подкормки, норма и дозировка рабочего раствора (в мл на 10 л воды) } \\
\hline & \multicolumn{2}{|c|}{ некорневая } & \multicolumn{2}{|c|}{ корневая } \\
\hline & рассады в фазе 2-3 листьев & $\begin{array}{c}\text { в период плетеобразования } \\
\text { и цветения }\end{array}$ & $\begin{array}{c}\text { в период высадки (в лунки) } \\
\text { рассады в грунт }\end{array}$ & $\begin{array}{c}\text { после первого сбора } \\
\text { урожая }\end{array}$ \\
\hline Контроль & \multicolumn{4}{|c|}{ Дистиллированная вода } \\
\hline Биогумус & 225 & 225 & 150 по 0,5 л раствора в лунку & $\begin{array}{c}150 \text { по } 1 \text { л раствора под каждое } \\
\text { растение }\end{array}$ \\
\hline Гуми & 7,5 & 7,5 & 7,5 по 0,5 л раствора в лунку & $\begin{array}{c}\text { 7,5 по } 1 \text { л раствора под каждое } \\
\text { растение }\end{array}$ \\
\hline Альбит & 0,6 & 0,6 & 0,6 по 0,5 л раствора в лунку & $\begin{array}{c}\text { 0,6 по } 1 \text { л раствора под каждое } \\
\text { растение }\end{array}$ \\
\hline
\end{tabular}


фазам вегетативного роста для соотношения Биогумус: Гуми: Альбит: контроль, то можно четко увидеть результаты действия биопрепаратов на динамику нарастания площади листьев. Это соотношение составляло для рассадного периода 94,8:97,9:89:80,4, для фазы плетеобразования - 241,3:243,6:260:219, для фазы массового цветения - 385,6:398,3:391,3:336,3 и для фазы массового плодоношения - 414,3:426,6:430:358,6. Следовательно, биопрепараты способствовали усиленному нарастанию и поддержанию ассимиляционного аппарата растений в течение всего вегетационного периода. Особенно эффективное действие оказывали Альбит и Биогумус [6].

Биопрепараты оказывали эффективное воздействие на фотосинтетический потенциал (ФП) растений огурца всех гибридов, но самое эффективное воздействие биопрепаратов на ФП отмечалось при обработке Биогумусом и Альбитом, где зафиксированы высокие показатели ФП на гибридах $F_{1}$ Апрельский 792417 м²дни/м², $F_{1}$ Арина 944784 м²д-

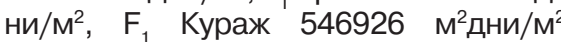

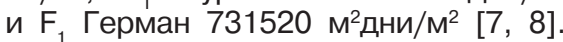
Фотосинтетический потенциал растений по сравнению с контролем был в среднем выше на 120-220 м²дни/м².

Наши исследования показали, что биопрепараты положительно влияли не только на рост и развитие, но также повышали урожайность товарных плодов. Товарная урожайность плодов в первую очередь зависела от правильной формы и размера плода. Так, например, к недостаткам контрольных растений гибрида $F_{1}$ Кураж следует отнести более низкую товарность, связанную с наличием сросшихся плодов уродливой формы, у $F_{1}$ Маша наблюдались плоды грушевидной формы. Такие показатели при учете снижали товарную урожайность и общую урожайность.

Учет урожая, определение количества плодов и их массы проводили по методике Б.А. Доспехова.

Высокая урожайность и товарность плодов огурца наблюдалась в варианте с Биогумусом: $F_{1}$ Арина -

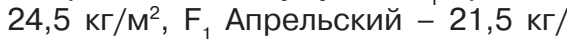
$\mathrm{M}^{2}, \mathrm{~F}_{1}$ Кураж - 19,1 кг/ $\mathrm{M}^{2}\left(\mathrm{HCP}_{0,5} 3,7\right)$. Товарность в среднем составила около 98\% (HCP $\left.{ }_{0,5} 3,2\right)$. C препаратом Гуми наиболее высокую урожайность показали гибриды: $F_{1}$ Арина -

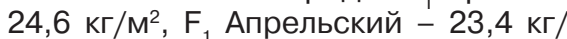

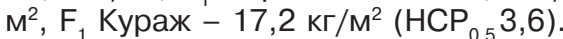
Товарность составила - 97,8\%
$\left(\mathrm{HCP}_{0,5} 3,4\right)$. Препарат Альбит показал следующие результаты по исследуемым гибридам: $F_{1}$ Арина -

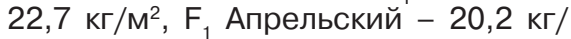

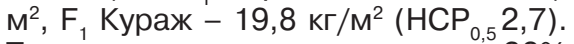
Товарность плодов составила - 96\% $\left(\mathrm{HCP}_{0,5} 4,1\right)$. Тогда как у контрольных растений самая низкая урожайность товарных плодов отмечалась у гибрида $F_{1}$ Герман - 10,7 кг/M², а самая высокая у гибрида $F_{1}$ Арина - 20,0 кг/ $\mathrm{M}^{2}\left(\mathrm{HCP}_{0.5} 3,5\right)$, товарность плодов составила 2,7\% ( $\left.\mathrm{HCP}_{0,5} 3,1\right)$.

Выводы. Для увеличения урожайности товарных плодов огурца в пленочной весенне-летней теплице при соблюдении агротехнических требований и создания оптимальных условий среды при выращивании растений эффективно проведение своевременных подкормок биопрепаратами Биогумус, Гуми и Альбит. Используя эти биопрепараты, можно получить урожай на 8-10 дней раньше, по сравнению с контролем.

Биопрепараты положительно влияли на рост, развитие и увеличение ассимиляционной поверхности листьев, усиливая интенсивность фотосинтеза, и повышая фотосинтетический потенциал растений по сравнению с контролем на 120-220 м²дни/м².

Корневая подкормка биопрепаратами в период плодоношения увеличила урожайность товарных плодов по всем гибридам от 17,2 до 24,6 кг/ $\mathrm{M}^{2}$, а товарность на 92-98\%. Самыми отзывчивыми оказались гибриды $F_{1}$ Арина, $F_{1}$ Апрельский и $F_{1}$ Кураж.

\section{Библиографический список}

1.Смашевский Н.Д. и др. Микроэлементы и биопрепараты в повышении продуктивности сельскохозяйственных культур в условиях поймы и дельты Волги: монография. Астрахань, 2014. 149 с.

2.Доспехов Б.А. Методика полевого опыта (с основами статистической обработки результатов исследований). М.: Агропромиздат, 1985. 351 с

3.Арсланова Р.А. Влияние биопрепаратов на хозяйственно-биологические особенности ранних гибридов огурца в пленочной теплице: дис. ... канд. с-х. наук. Астрахань, 2009. 169 с.

4.Арсланова Р.А. Влияние биологически активных веществ при выращивании раннеспелых сортов огурца в весенне-летней теплице // Естественные науки. 2009. № 2. С. 59-61.

5.Белик В.Ф. Овощеводство. М.: Колос, 1981. 383 с. 6.Ионова Л.П., Арсланова Р.А. Отзывчивость ранних сортов огурца на действие биопрепаратов в защищенном грунте при пленочном укрытии // Аграрный вестник Урала. 2009. № 3. С. 86-91.

7.Брызгалов В.А., Советкина В.Е., Савинова, Н.И. Овощеводство защищенного грунта. М.: Колос, 1983. 352 с. 8.Третьяков Н.Н., Панечкин Л.А., Кондратьев М.Н. Практикум по физиологии растений. М.: КолосС, 2003. $640 \mathrm{c}$.

\section{Об авторах}

Арсланова Румия Ахтямовна, канд. с. - х. наук, доцент, зав. кафед- рой агротехнологий, инженерии и агробизнеса, Федеральное государственное бюджетное образовательное учреждение высшего образования «Астраханский государственный университет» (ФГБОУ «АГУ»).

E-mail: rumiya-arslanova@mail.ru

Ионова Лидия Петровна, канд. С. х. наук, доцент, профессор кафедры агротехнологий, инженерии и агробизнеса, ФГБОУ «АГУ».

E-mail: ion-lida@yandex.ru

Вилкова Жанна Анатольевна, канд. c. - х. наук, доцент кафедры агротехнологий, инженерии и агробизнеса, ФГБОУ «АГУ».

\section{E-mail: zim-zhanna@mail.ru}

\section{Бабакова Анна Сергеевна, канд.} c. - х. наук, доцент кафедры агротехнологий, инженерии и агробизнеса, ФГБОУ «АГУ».

E-mail: anntyanettka@mail.ru Анишко Михаил Юрьевич, канд. c. - х. наук, доцент кафедры агротехнологий, инженерии и агробизнеса, ФГБОУ «АГУ»

Growing peculiarities of a cucumber in the spring and summer greenhouse with application of biopreparations

R.A. Arslanova, PhD, assoc. prof., head of Department of agrotechnology, engineering and agribusiness, Astrakhan State University.

E-mail: rumiya-arslanova@mail.ru L.P. Ionova, PhD, assoc. prof., professor of the Department of agrotechnology, engineering and agribusiness, Astrakhan State University. E-mail: ion-lida@yandex.ru Zh.A. Vilkova, PhD, assoc. prof. of the Department of agrotechnology, engineering and agribusiness, Astrakhan State University. E-mail: zim-zhanna@mail.ru A.S. Babakova, $P h D$, associate

professor, assoc. prof. of the Department of agrotechnology, engineering and agribusiness, Astrakhan State University. E-mail: anntyanettka@mail.ru

M.Y. Anishko, PhD, assoc. prof. of the Department of agrotechnology, engineering and agribusiness, Astrakhan State

University

Summary. The article presents the results of studies on the effect of biological products Biohumus, Gumi and Albite on earlymaturing cucumber hybrids grown in protected soil. In the course of the work it was found that timely fertilizing with biopreparations responsive to their introduction of hybrids, contributed to the increase in plant growth processes, from seed germination to the end of fruiting, increased yield and marketability of fruits.

Keywords: greenhouse, cucumber hybrids, biopreparations, productivity of plants, commercial fruit yield. 